Studia i materiały z dziedzictwa kulturowego Torunia i regionu, t. 1: STARE I NOWE DZIEDZICTWO TORUNIA,

Toruń 2013

http://dx.doi.org/10.12775/SiMzDzKTiR_T1.2013.012

Anna Bystroń-Kwiatkowska

(TORUŃ)

\title{
Malarski wystrój wnętrza kamienicy przy Rynku Staromiejskim 20 w Toruniu
}

Kamienica mieszczańska położona przy Rynku Staromiejskim 20 w Toruniu posadowiona jest w zwartej zabudowie na parceli gotyckiej, wytyczonej około połowy XIII wieku ${ }^{1}$ Kamienica już bardzo wcześnie zaczęła być poddawana kolejnym przebudowom - jej wnikliwa i obszerna analiza zabytkoznawcza, przeprowadzona przez Ewelinę Nawrocką ${ }^{2}$ ujawnia, iż już w okresie średniowiecza, bo około 1500 roku, można wyodrębnić sześć etapów przebudowy. Zmiany średniowieczne i dalsze w okresie nowożytnym, w XVIII, XIX i XX wieku dają się odczytać w dekoracjach malarskich ścian i stropów kamienicy. Badania historyczne i architektoniczne w budynku wykonał też Robert Paszkowski ${ }^{3}$, podkreślając „bardzo wysoki poziom wartości zabytkowej" kamienicy. Mimo tych wielokrotnych ingerencji i zmian, budynek zachował czytelny układ średniowieczny, spotykany w nieomal wszystkich kamienicach mieszczańskich Torunia.

Budynek główny w zabudowie działki był trójosiowy, dwukondygnacyjny, dwutraktowy. W trakcie przednim parteru znajdowała się głęboka, wąska Wysoka Sień. Za nią, w trakcie tylnym, usytuowana była niższa izba na planie nieomal kwadratu, a na piętrze traktu tylnego znajdowało się pomieszczenie powtarzające proporcje parteru (il. 1). Wymienione pomieszczenia kryte były polichromowanymi stropami: Wysoka Sień - belkowo-deskowym, parter tylnego traktu brusowo-belkowym, piętro tylnego traktu podwójnym - brusowo-belkowym i belkowo-deskowym. Wyniki badań dendrochronologicznych ${ }^{4}$, które przeprowadzono na

1 Jest to wąska a wydłużona działka sięgająca pierwotnie od Rynku do ul. Franciszkańskiej.

2 Ewelina NAWROCKA, Kamienica przy Rynku Staromiejskim 20 w Toruniu. Analiza zabytkoznawcza budynku, Toruń 2011, kps w biurze Miejskiego Konserwatora Zabytków w Toruniu. Por. także artykuł tej autorki $\mathrm{w}$ niniejszym tomie.

3 Robert PASZKOWSKI, Toruń Rynek Staromiejski 20. Dokumentacja konserwatorska, T. 2, Badania historyczne i architektoniczne, Toruń 2008.

4 Aleksander KONIECZNY, Ekspertyza dendrochronologiczna. Toruń, kamienica Rynek Staromiejski 20, Toruń 2011. 
wielu elementach konstrukcji drewnianych kamienicy, dały bardzo ciekawe wyniki, dodatkowo utwierdzając badaczy w ustalaniu dat powstania malowideł.

Wspomniane zmiany zachodzące we wnętrzach kamienicy były skutkiem przekształceń pomieszczeń mieszkalnych zgodnie z regułami nowej mody lub nowej funkcji. Przede wszystkim kilkakrotnie zamalowano białą farbą polichromię stropu Wysokiej Sieni i stropu izby piętra tylnego traktu. Powszechnym zwyczajem w XIX wieku było wprowadzanie w kamienicach płaskich sufitów - zmiany takie przeprowadzono również w omawianym budynku. Do strony licowej belek podbijano deski, na które nabijano maty trzcinowe, na trzcinę narzucano tynk i całość grubo bielono, uzyskując gładki biały sufit. W przypadku Wysokiej Sieni w przestrzenie między deskami i belkami a nowe oszalowanie włożono mocno ubity mech z mierzwą i sypką gliną. Wypełnienia takie były często stosowane jako warstwy wygłuszające, ocieplające i regulujące wilgotność pomieszczeń. Po usunięciu oszalowania sufitu ukazał się pobielony strop z wyłaniającą się spod przemalowań widoczną polichromią. Jego sfazowane belki ułożone były równolegle do ściany frontowej. Na belkach ułożono na profilowaną zakładkę bardzo długie i szerokie deski (il. 2).

Po oczyszczeniu dwuwarstwowych pobiał i usunięciu zabrudzeń, takich jak kurz, kopeć, brązowe i czarne zacieki (w miejscach przy węzłach kanalizacyjnych), na deskach odsłonięto polichromie w formie wydłużonego i rozbudowanego ornamentu rocaillowego. Ornament malowany na ugrowo-żółtym tle, utrzymany był w kolorze błękitu, podkreślony granatowymi cieniami i światłami w kolorze złamanej bieli (il. 3). Rocaillowe formy zakomponowano w dwóch pasmach, po obu stronach podciągu. Malowano je nad głową na już ułożonych deskach stropu (il. 4). Na żadnym z fragmentów tynku, wielokrotnie miejscowo przemurowywanych ścian Wysokiej Sieni, nie zachowały się ślady polichromii.

Kolejne pomieszczenie parteru, zlokalizowane w tylnym trakcie, pełniło funkcje reprezentacyjne - przyjmowano w nim godnych i znamienitych gości, toczyło się tam życie rodzinne. W izbach takich w średniowiecznych domach Torunia znajdowano w trakcie badań architektoniczno-konserwatorskich ślady wylotów hypocaustum, czyli ślady ogrzewania ciepłym powietrzem. Były to więc pomieszczenia ocieplane i bogato zdobione. Tak też jest w przypadku omawianej kamienicy, gdzie dbałość o estetykę wnętrza była szczególna i długo podtrzymywana. Tu również, wprowadzając płaski sufit, podbito do spodu belek deski. Zapewne belki były za duże, gdyż ich spody znacznie i brutalnie obciosano, częściowo je niszcząc. W trakcie prac remontowych, po odjęciu desek sufitu odkryto malowane tkaniny plafonowe, rozpostarte między belkami, przybite do nich profilowanymi listwami.

Omówienie malarskich zdobień stropu tego pomieszczenia jest o tyle utrudnione, iż na dekorację tą składa się spora różnorodność użytych materiałów, technik i stylów rozrzuconych w czasie, a dotyczy to wielokrotnie przemalowywanych pasów tkaniny (między belka$\mathrm{mi}$ ) oraz usytuowanego pod tkaniną, przemalowanego średniowiecznego stropu belkowodylowego. Opis rozpoczynamy od części najstarszej - stropu belkowo-dylowego, który tworzyły grube dyle, ułożone prostopadle do ściany północnej, łączone na obce pióro i wsparte na trzech belkach. Ocenę dendrochronologiczną czasu użycia dyli wyliczono na 
około 1375 roku, chociaż znalazł się też dyl z drzewa ściętego w 1286 roku5.

Najstarsza warstwa malarska, leżąca na cienkim białym gruncie, jest bardzo zniszczona. Zachowały się z niej tylko nieliczne, niewielkie fragmenty znajdujące się we wgłębieniach niestarannie obciosanych powierzchni dyli. W tej warstwie można zauważyć kolory używanych farb, takie jak zieleń (zbliżona do ziemi zielonej), czerwień (zbliżona do cynobru), ugier i czerń. Śladów tej warstwy nie znajdujemy na szczątkach pasów płótna, które przyklejono na stykach dyli. Następną warstwę polichromii położono na wyżej opisanej, bez oczyszczenia czy przeszlifowania lica dyli, wprowadzając jedynie miejscowo cienką warstwę białego, ścisłego gruntu. Na trzech belkach podtrzymujących dyle, to jest przyściennej (od strony południowej) i dwóch następnych, nie zachował się żaden ślad pierwszej warstwy, a druga została zniszczona przez XIX/XX-wieczne olejne przemalowanie i XX-wieczne obciosania spodów belek przed oszalowaniem położonym pod tynk sufitu (il. 5). Polichromia na dylach zachowała się bez przemalowań i korekt, poza ponownym zalepieniem styków pasami płótna. Na powierzchni dwunastu dyli i na dzielących je trzech belkach zakomponowano 36 prostokątnych pól, z których każde na szerokości dyla obrzeżone jest namalowaną podwójną wąską i szerszą jednobarwną ramą. Każde pole stropu ma wewnątrz inną ornamentalną kompozycję. Wracając do zalepionych styków dyli można założyć, że pierwotnie szpary między dylami mogły zakrywać przybite listwy, o czym świadczą zachowane gdzieniegdzie rzędy otworów po gwoździach. Być może w trakcie użytkowania pomieszczenia styki stały się nieszczelne i wysypywały się z nich szczątki mierzwy, mchu i gliny, którymi pierwotnie uszczelniono wzdłużne rowki przeznaczone na obce pióro. Odwrocia niektórych dyli były przesmarowane papką z gliny (rodzaj polepy).

Polichromie w prostokątnych ramach w znacznym stopniu dają się odczytać. Po odczyszczeniu powierzchni malowidła gumkami (mechanicznie) i różnymi roztworami (chemicznie) ukazały się niezwykle barwne i różnorodne przedstawienia oraz ornamenty (il. 6). Ułatwieniem w odczytywaniu ornamentów był w znacznej mierze ich manierystyczny „standard”, stosowanie form znanych nam z używanych powszechnie od XVI wieku wzorników. Można założyć, że polichromie nanoszono na dyle, malując nad głową - na zamontowanym już stropie. Malarz dysponował szablonami stosownej wielkości, które przyłożone do odpowiedniego pola na dylach wyznaczały oś kompozycji, ogólny zarys form i inne pomocnicze punkty. Niektóre prostokąty szablonów nie dały się nanieść na podział dyli, gdyż całość pomieszczenia nie była równym kwadratem, a miała lekkie skosy narożników. W takich miejscach malarz dopasowywał ornament malując swobodną kompozycję, a wykańczające całość malowane ramy zakrywały wystające poza nie formy. Niewątpliwie twórca ten dysponował dużym talentem, bogatą paletą barw oraz znajomością wielu różnych kompozycji ornamentalnych. W kolejnych prostokątach na dylach widzimy asymetryczną maureskę, arabeskę z wplecionymi głowami zajęcy i gryfów, wizerunek papugi, ornament florystyczny z pękami kwiatów i owoców (il. 7) podwieszonych na bogato wijących się wstęgach, głowy aniołków wyrastające $z$ kwiatów, otoczone dekoracyjnymi skrzydełkami (il. 8), twarze kobiet otoczone fantazyjnie upiętymi podwikami z nakładkami lub kornetami (il. 9), łączące

5 KONIECZNY 2011, s. 2. 
się z resztą kompozycji wstęgami, nanizanymi na taśmę kulkami i cekinami. Na prostokątnych polach namalowano też kaboszony i rauty w ramach $z$ ornamentu okuciowego zwijanego, wplecione w wić kwiatową i w tkaniny w formie podwieszonych lambrekinów, rogi obfitości i kosze jabłek, gruszek, winogron, granatów. Niektóre pola wypełnia spokojniejsza kompozycja plecionki lub wieńca liści, przewiązanego wstęgą. Wszystkie te elementy malowane są z dużą swadą i wprawą w operowaniu grubym pędzlem (efekt plastyczności, różnicowanie szerokości duktu pędzla); należy tu również podkreślić, że całość stropu malowana jest z palety. Bogata kolorystyka kompozycji ornamentalnych wskazuje na różnorodność farb używanych przez twórcę. Widzimy tu wiele czerwieni, różne żółcienie (od cytrynowej do pomarańczowej), zróżnicowane zielenie, fiolety; nie spotykamy za to żadnych błękitów. Mieszanie farb na palecie pozwoliło malarzowi uzyskiwać efekt przechodzenia barw i odcieni nieomal jak w malarstwie sztalugowym. Niewątpliwie dysponował on wzornikami, które pojawiały się w tej części Europy od XVI wieku. Być może na tym stropie nawiązywał do wzorników Teodora de Bry6.

Mimo możliwości odczytania barw i pojedynczych form ornamentu, uzupełnienia estetyczne większości kompozycji nie są możliwe. Maestria malarza oraz jego swoboda prowadzenia ornamentu jest zasadniczą i poważną przeszkodą w uzupełnieniach malowideł (il. 10). Nie mamy możliwości odczytania wielu pasm wstęg i nanizanych nań drobnych detali, jak kampanule, pierścienie, cekiny; nie wiemy jak przebiegał ornament typu maureska - nic się nigdzie nie powtarza. W głąb warstwy malarskiej przeniknęły sczernienia sadzy i kopcia, występują wypłukania warstw aż do drewna oraz ślady ekskrementów owadów. Wszystkie wymienione zniszczenia są nieomal nie do usunięcia.

Ściemnienie, czy wręcz sczernienie malowidła tego stropu stało się zapewne przyczyną decyzji o zmianie dekoracji pomieszczenia, nie przez przemalowanie stropu dylowo-belkowego, a przez inne udekorowanie - podpięcie na listwach do boków belek pasm płótna i malowanie ornamentów na takim podłożu.

Pośród bardzo wielu kamienic Torunia z zachowanym malarskim wystrojem wnętrza, tylko raz odkryto malowany plafon (nie licząc płótna plafonu w Ratuszu). W naszej kamienicy polichromowane płótna przykrywały trzy przestrzenie międzybelkowe. Niestety do naszych czasów przetrwały tylko dwa i część trzeciego. Najmłodsza warstwa malarska malowidła na pasach płótna miała ciemną kolorystykę, mieszczącą się w konwencji XIX wieku. Na gładkim, ciemno-błękitno-zielonawym tle zakomponowano na osi stropu, w przestrzeniach międzybelkowych, trzy duże, szerokie, klasycyzujące w formie wazy (il. 11) utrzymane w odcieniach ugru. Niebiesko-zielonkawego koloru były również ściany pokoju, na których wydzielono malowanymi bordiurami rodzaj płycin (il. 12). Bordiury były koloru ugrowego, z plecionką prymitywnie malowaną czernią. Jest to XIX-wieczne, najbliższe nam w czasie malarskie zdobienie pomieszczenia (il. 13).

Na pasmach płótna, pod opisaną XIX-wieczną dekoracją, znajdowała się warstwa malarska, również olejna, lecz słaba technologicznie (bardzo krucha), w formie geometrycznych podziałów, utrzymana w kolorach błękitno-szaro-biało-czarnych. Następna warstwa, znacz- 
nie lepiej zachowana i ciekawiej zakomponowana, jest kolorystycznie zbliżona. Na błękitnym tle pasm płótna namalowano w technice olejnej lekko i elegancko ornament rocaillowy, utrzymany w błękitach, bielach, kolorze ciemnoniebieskim i granatowym (il. 14). Zakomponowano go tak, że tworzy większe formy w punkcie centralnym i w narożnikach, wokół mając puste przestrzenie. Pod tą warstwą, którą możemy określić jako pochodzącą z około 1760 roku (il. 15) znajduje się jeszcze jedno malowidło - wykruszone, z ubytkami, lecz czytelne w kompozycji i kolorze. Symetryczną kompozycję pasów płócien tworzą tu duże, mięsiste, skręcone wici akantu (w kolorze szaro-ugrowym i mocnej czerwieni) tworzące pasowe, łamane wstęgi i wstęgowo-cęgowe połączenie $\mathrm{z}$ akantem (il. 16). Wić akantu i ornament wstęgowo-cęgowy zaczynają się od centralnego punktu pasa stanowiącego oś kompozycji w formie kampanulowego kwiatonu, a całość obejmuje malowana szeroka, brązowa rama.

Kolejność warstw malarskich występujących na stropie tego pomieszczenia możemy zatem opisać następująco:

1. najstarsza, średniowieczna, leżąca na belkach i dylach, bardzo słabo zachowana;

2. manierystyczna, pochodząca z końca XVI wieku, położona na belkach (?) i dylach;

3. pochodząca prawdopodobnie z końca XVII wieku, malowana na pasmach płótna (i belkach?);

4. rokokowa, XVIII-wieczna, malowana na pasmach płótna (i belkach?);

5. klasycyzująca, malowana na pasmach płótna w podziałach geometrycznych;

6. klasycystyczna, XIX-wieczna, malowana na pasmach płótna, belkach i ścianach. Z powyższego wyszczególnienia wynika, że kolejni użytkownicy tego pomieszczenia wykazywali się dbałością o jego bogaty, reprezentacyjny wystrój.

Na pierwszym piętrze tylnego traktu, po zdjęciu odeskowania z przełomu XIX i XX wieku, tworzącego podkład pod tynkowany sufit, odsłonięto kolejny strop kamienicy. Jest to XVIII-wieczny strop belkowo-deskowy składający się z dwóch belek i czternastu desek. Belki tego stropu - przyścienna, od strony północnej i następna (druga) - są polichromowane; trzecia belka została dodana w nieznanym czasie, nie ma polichromii, lecz jest sfazowana, podobnie jak belki poprzednie. W drewnie polichromowanych belek intensywnie żerowały owady, były one też spękane już w XVIII wieku, w momencie przygotowywania ich do malowania. Deski stropu umocowano równolegle do belek (co jest rzadko spotykane w toruńskich stropach) podbijając je do dylowego stropu leżącego bezpośrednio nad nimi, a ułożonego prostopadle do ściany północnej (il. 17).

Dekoracji belek omawianego stropu nie można datować wcześniej, niż na okres baroku. Są one pokryte malowidłami, wykonanymi w technice olejnej, leżącymi bezpośrednio na drewnie. Drewno belek jest bardzo niestarannie przygotowane, ma nierówną powierzchnię, jego spękania przykryto przyklejonym grubym płótnem. W świetle bocznym widoczne są znaczne nierówności - na jednym odcinku widać nawet korę sosnową, której nie usunięto przed malowaniem ornamentu. Na belce przyściennej widoczny jest ornament w formie płynnie i esowato prowadzonej wici roślinnej. Jest on widoczny na boku i na spodzie belki (zachowany tylko w połowie długości). Na sfazowaniu namalowano marmoryzację w trzech różnych kolorach. Druga belka ma na obu bokach ornament roślinny, na sfazowaniu mar- 
moryzację i na spodzie belki też rodzaj marmoryzacji. Malarz używał koloru ciemnej czerwieni jako tła wici, ornament malował ciemną zielenią, szarością i ciemnym ugrem. Światła ornamentu malowane były jasną zółcienią, cienie czernią. Kolory te powtarzają się w marmoryzacji. Malarz używał szerokiego pędzla, nakładając na przykład światła tak impastowo, że tworzyły się wysokie fakturalnie linie, a w przypadku marmoryzacji - wzniesione formy kropek, trójkątów i pasów.

Deski malowane były inną techniką i bardzo różnią się od belek kolorystyką. Drewno lica i odwrocie desek miało niewiele uszkodzeń, szczególnie gładko opracowane było lico (desek). Na jasno-błękitno-szarym tle (prawdopodobnie technika chudej tempery) namalowane zostały wzdłuż desek ornamenty rocaillowe, utrzymane w kolorze złotego ugru, z biało-żółtawymi światłami i brązowo-szarawymi cieniami, pogłębionymi drugą linią ciemniejszego błękitu (il. 18). Ornament jest malowany lekko, swobodnie i gładko.

Prawdopodobnie belki i deski malowane były do różnych stropów, w nieodległym czasie, lecz wyraźnie przez różnych malarzy, a następnie złożone w całość w obecnym pomieszczeniu. Zarówno belki, jak i deski tego stropu zostały dwu-, a miejscami trzykrotnie pobielone, z tym, że deski przed pierwszym pobieleniem oczyszczono na mokro, o czym świadczą smugi rozmytego brązu i ugru.

Jak wspomniano, deski stropu belkowego z rokokową dekoracją podbito do ułożonych nad nimi dyli tworzących płaski strop (il. 19). Dyle łączone są na obce pióro (to należy jeszcze sprawdzić, aby być pewnym), a styki pierwotnie zalepiono pasami płótna. Na tak przygotowaną powierzchnię naniesiono polichromię (prawdopodobnie w technice klejowej), a następnie monochromię w kolorze ugru. Drewno stropu zostało wydatowane przez dendrochronologa i opisane w komentarzu do ekspertyzy dendrochronologicznej jako strop dylowy, który można „datować na trzecią tercję XIII wieku i tym samym uznać za najstarszy

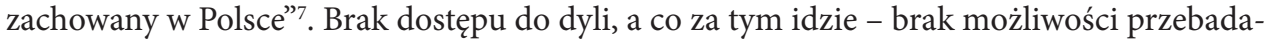
nia stropu, każe poczekać z wnioskami do czasu wznowienia prac budowlano-remontowych.

Nagie drewno dyli, widoczne na odsłoniętych spod oderwanych pasów płótna, może być efektem zerwania warstwy malarskiej przez klej na płótnie lub świadectwem, iż do około 1750 roku. dyle były przykryciem pokoju na piętrze i pomalowane były farbą w kolorze ugru. Na przestrzeniach międzybelkowych i na pobiałach ścian znajdowano bardzo małe fragmenty polichromii, których nie udało się dopasować do żadnej warstwy malarskiej na stropie, ani połączyć w czytelną formę.

Częste przebudowy, remonty, zmiany poziomów stropów odbiły się negatywnie na stanie zachowania podłoża ceglanego, tynków i pobiał ścian kamienicy. Mimo częstego natrafiania w trakcie badań konserwatorskich na barwne ślady na pobiałach bądź w miejscach umieszczania fryzów podstropowych, nie udało się odczytać kształtu ornamentu lub określić barwne formy. Wyjątkiem była polichromia na ścianie zachodniej pomieszczenia pierwszego piętra traktu tylnego, utrzymana w zróżnicowanej walorowo szarości. Był to być może iluzjonistycznie malowany podział ściany, lecz i tu zachowany fragment był tak niewielki,

7 KONIECZNY 2011, s. 9. 
iż nie dopasowano go do żadnego innego zdobienia pokoju.

Wśród właścicieli kamienicy, wymienionych przez Krzysztofa Mikulskiego ${ }^{8}$ starałam się znaleźć rodziny zamieszkujące ją dłużej i może dlatego zdobiące jej wnętrza pięknymi i modnymi malowidłami. Znalazłam rodzinę Bodenstein, która zamieszkiwała dom długo - aż przez 59 lat (1549-1606). Możliwe, że to na jej zlecenie utalentowany malarz wykonał manierystyczne dekoracje stropu parteru tylnego traktu. Z kolei, w latach 1737-1793 w domu przez ponad półwiecze mieszkała bogata rodzina piernikarzy, którą spajała postać wdowy Schreiber wychodzącej czterokrotnie za mąż, za każdym razem za piernikarza. Tej rodzinie można przypisać zlecenie rokokowej dekoracji stropów Wysokiej Sieni, malowanej tkaniny z parteru tylnego traktu oraz rokokowych zdobień stropu z piętra tylnego traktu.

Nie mamy wystarczających danych, dotyczących wystroju wnętrz kamienic mieszczańskich Torunia. Nie wiemy, jakie tkaniny, obrazy, kolekcje broni, przyrządy astronomiczne i inne, ani jakie księgi wypełniały domy mieszczan, podkreślając reprezentacyjność pomieszczeń i prestiż ich właścicieli. Za to z całą pewnością znajduje się w naszym mieście bardzo duża liczba kamienic z zachowanymi historycznymi układami wnętrz, malowidłami ściennymi, a przede wszystkim polichromowanymi stropami. Opisywana kamienica przy Rynku Staromiejskim 20 jest kolejnym nieznanym dotąd obiektem, ukazującym wnętrze domu mieszczanina i jego historyczno-stylowe przemiany na przestrzeni kilkuset lat.

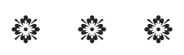

\section{The painting décor inside the burghers house located in the old city market in torun}

the paper contains information about the newest discoveries made in the historical monument of a rich burghers house located in the area of the medieval Old City Market in Torun at number 20.

This small, narrow and low building, which is only about $5.4 \mathrm{~m}$ wide and has 3 floors - is probably one of the very oldest in the town. It was repeatedly rebuilt according to the needs of its owners and converted to the new functions connected with the owners' activities. However, the house preserved many relevant architectural relics such as - the marks (traces) of the vaults on the walls, the remains of hypocaust, a section of wooden staircase, even a built-in cabinet. But the most significant and interesting discovery was 4 polychromy ceilings from the $13^{\text {th }}, 16^{\text {th }}$, $18^{\text {th }}$ cent., and a painting plafond from the $17^{\text {th }}$ cent. - which are described in detail in this report.

8 Krzysztof MIKULSKI, Właściciele i funkcje działek $w$ kwartale mariackim Starego Miasta Torunia od końca XIV w. do początku XIX w., Toruń 2008 


\section{SPIS ILUSTRACJI}

1. Toruń, kamienica przy Rynku Staromiejskim 20. Przekrój podłużny i rzut parteru budowli z zaznaczoną lokalizacją opisywanych stropów (fot. inwentaryzacja L. Czyżniewska).

2. Strop belkowo-deskowy Wysokiej Sieni w trakcie odsłaniania spod oszalowania, fot. S. Socha-Bystroń.

3. Stan zachowania polichromii na deskach stropu Wysokiej Sieni. Widoczne przemalowania, wyłuszczenia i przebarwienia warstwy malarskiej, fot. S. Socha-Bystroń.

4. Polichromowane deski stropu Wysokiej Sieni po konserwacji, fot. S. Socha-Bystroń.

5. Pomieszczenie w trakcie tylnym parteru. Obciosane belki stropu, fot. L. Czyżniewska.

6. Pomieszczenie w trakcie tylnym parteru. Stan zachowania XVI-wiecznej polichromii na dylach stropu, fot. L. Czyżniewska.

7. Pomieszczenie w trakcie tylnym parteru. XVI-wieczna polichromia w formie owocowo-kwiatowej wiązanki po oczyszczeniu przed konserwacją, fot. A. Bystroń-Kwiatkowska.

8. Pomieszczenie $\mathrm{w}$ trakcie tylnym parteru. XVI-wieczna polichromia $\mathrm{w}$ formie główki aniołka, fot. A. Bystroń-Kwiatkowska.

9. Pomieszczenie $\mathrm{w}$ trakcie tylnym parteru. XVI-wieczna polichromia $\mathrm{w}$ formie głowy kobiecej, fot. A. Bystroń-Kwiatkowska.

10. Pomieszczenie w trakcie tylnym parteru. Polichromowane dyle po konserwacji, fot. A. Bystroń -Kwiatkowska.

11. Pomieszczenie w trakcie tylnym parteru. Odsłonięta spod oszalowania polichromowana tkanina i obciosane belki stropu, fot. L. Czyżniewska.

12. Pomieszczenie w trakcie tylnym parteru. XIX-wieczna waza malowana na pasmach płótna rozpostartych między belkami stropu, fot. S. Socha-Bystroń.

13. Pomieszczenie w trakcie tylnym parteru. Polichromia ścian - bordiura będąca kontynuacją malowideł plafonowych, fot. A. Bystroń-Kwiatkowska.

14. Pomieszczenie w trakcie tylnym parteru. Próby reperacji ubytków płótna plafonowego, ułożenie znalezionych fragmentów, fot. S. Socha-Bystroń.

15. Pomieszczenie w trakcie tylnym parteru. Odsłonięty spod XIX-wiecznych przemalowań ornament rocaillowy plafonu i leżący pod nim ornament okuciowo-pasowy, fot. S. Socha-Bystroń.

16. Pomieszczenie w trakcie tylnym parteru. Polichromowana tkanina po konserwacji,fot. S. Socha -Bystroń.

17. Pomieszczenie I piętra w tylnym trakcie. Widok stropu po odsłonięciu spod oszalowania, fot. A. Bystroń-Kwiatkowska.

18. Belki stropu z XVIII-wieczną polichromią. Nad belkami widoczne dyle z XIII w. pokryte warstwami malarskimi, fot. A. Bystron'-Kwiatkowska.

19. Pomieszczenie I piętra $w$ tylnym trakcie. Pomieszczenie I piętra w tylnym trakcie. Rocaillowa dekoracja stropu w trakcie prac konserwatorskich, fot. A. Bystroń-Kwiatkowska. 

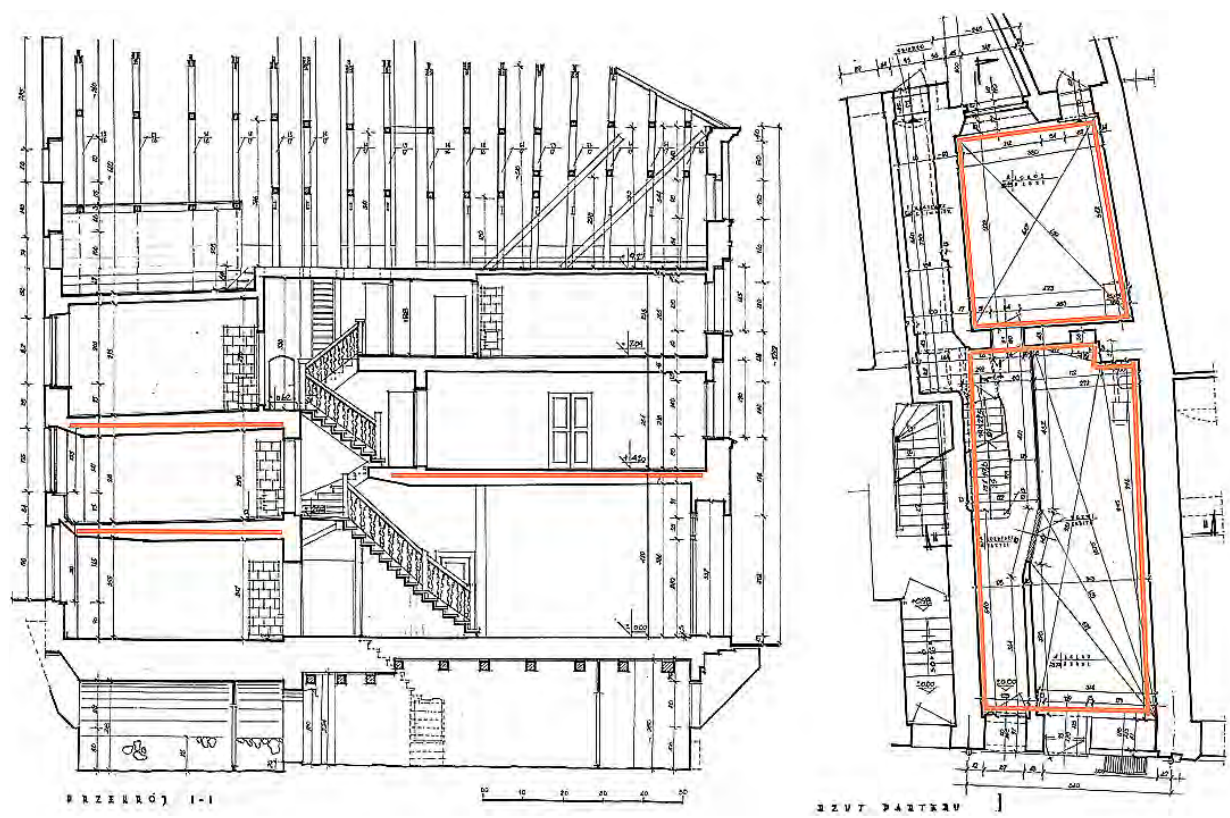

Il. 1 Toruń, kamienica przy Rynku Staromiejskim 20. Przekrój podłużny i rzut parteru budowli z zaznaczoną lokalizacją opisywanych stropów (fot. inwentaryzacja L. Czyżniewska)

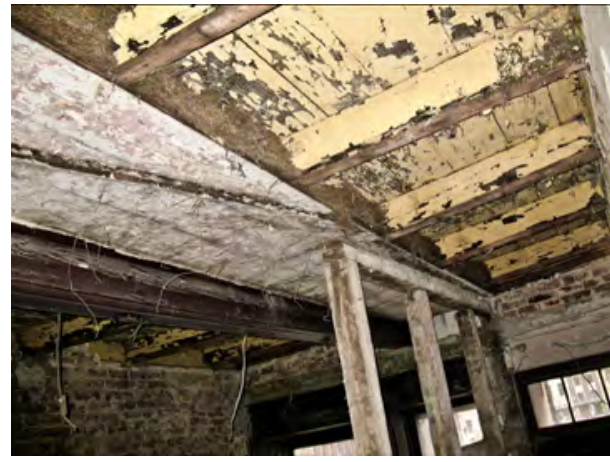

Il. 2 Strop belkowo-deskowy Wysokiej Sieni w trakcie odsłaniania spod oszalowania, fot. S. Socha-Bystroń

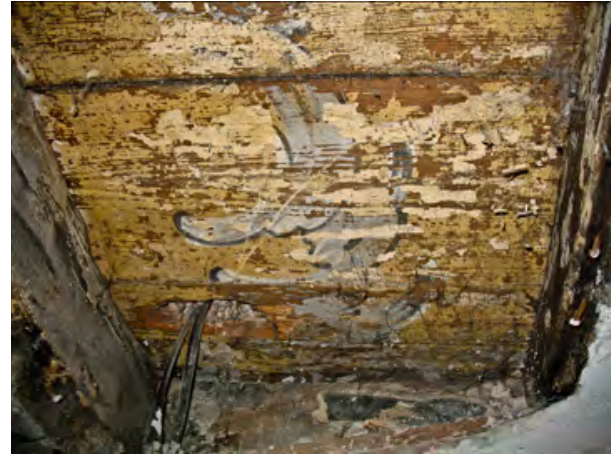

Il. 3 Stan zachowania polichromii na deskach stropu Wysokiej Sieni. Widoczne przemalowania, wyłuszczenia i przebarwienia warstwy malarskiej, fot. S. Socha-Bystroń 


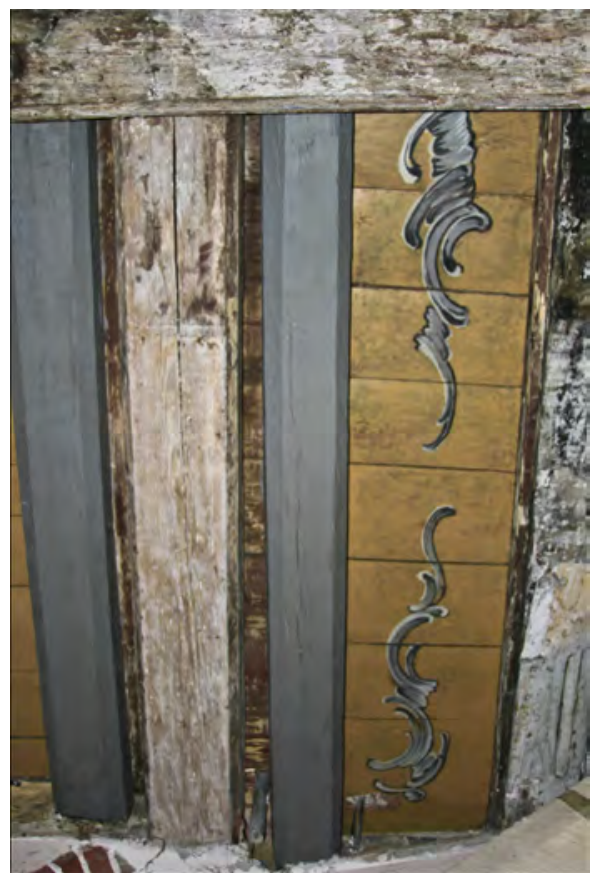

Il. 4 Polichromowane deski stropu Wysokiej Sieni po konserwacji, fot. S. Socha-Bystroń

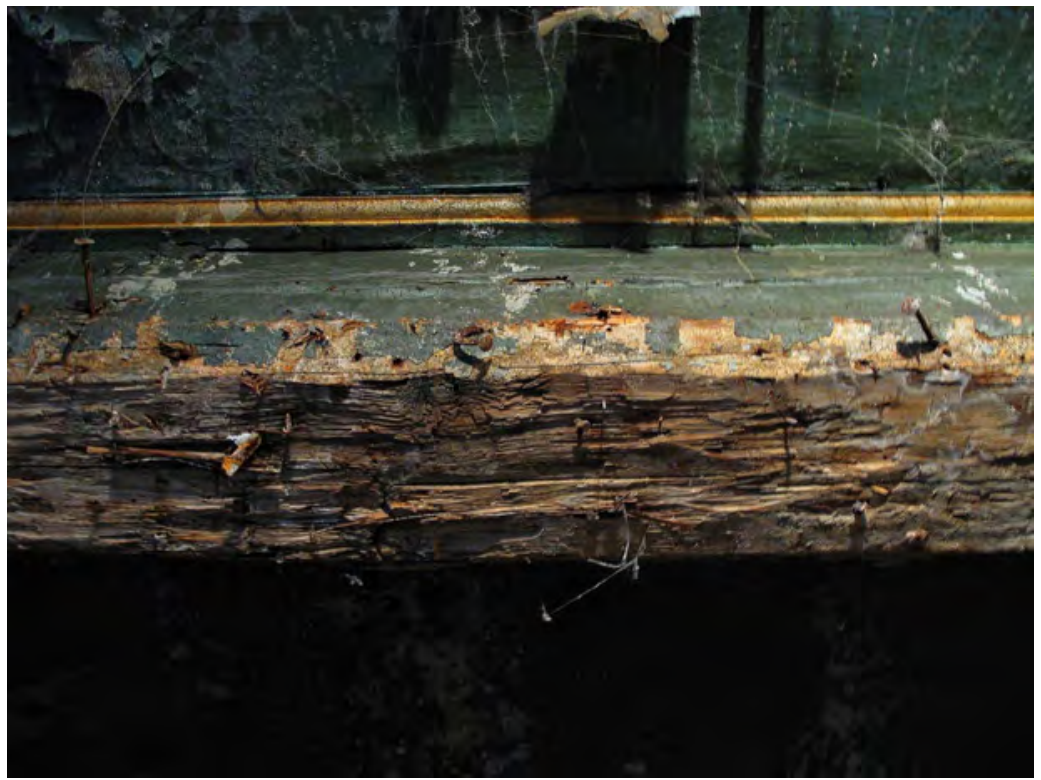

Il. 5 Pomieszczenie w trakcie tylnym parteru. Obciosane belki stropu, fot. L. Czyżniewska 


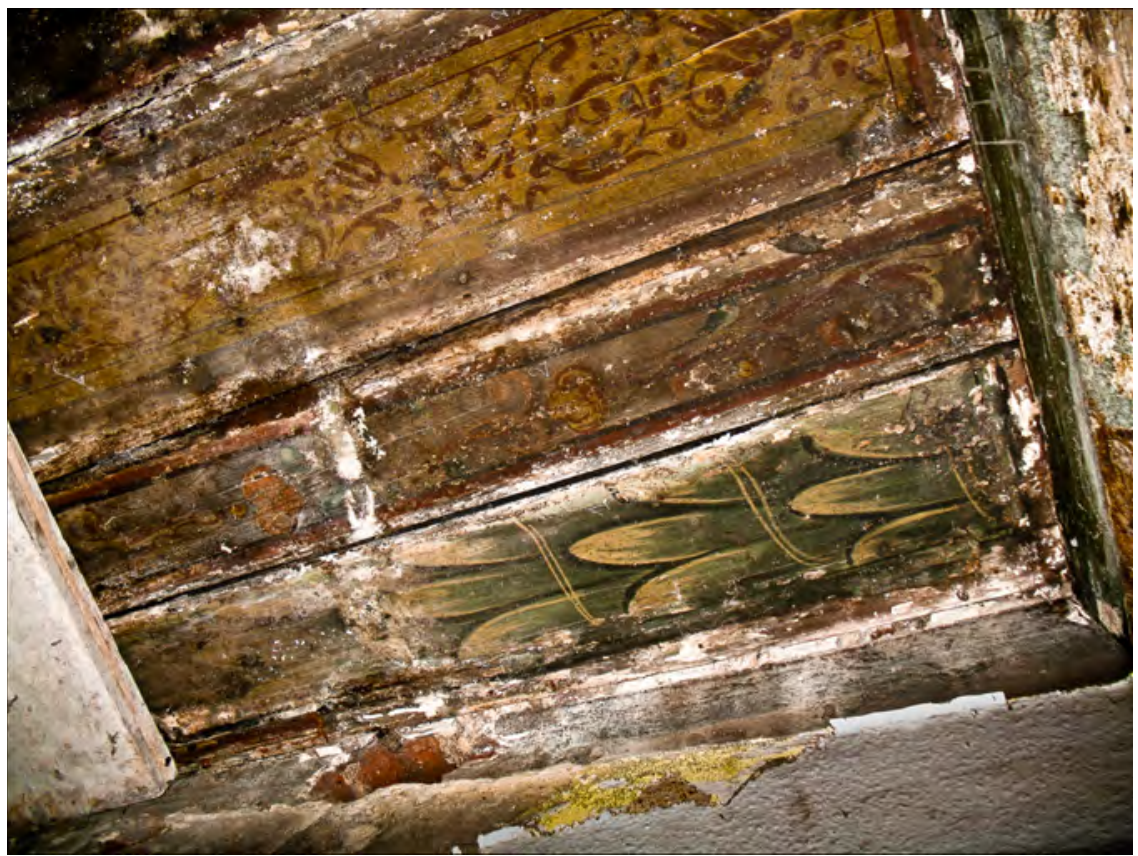

Il. 6 Pomieszczenie w trakcie tylnym parteru. Stan zachowania XVI-wiecznej polichromii na dylach stropu, fot. L. Czyżniewska

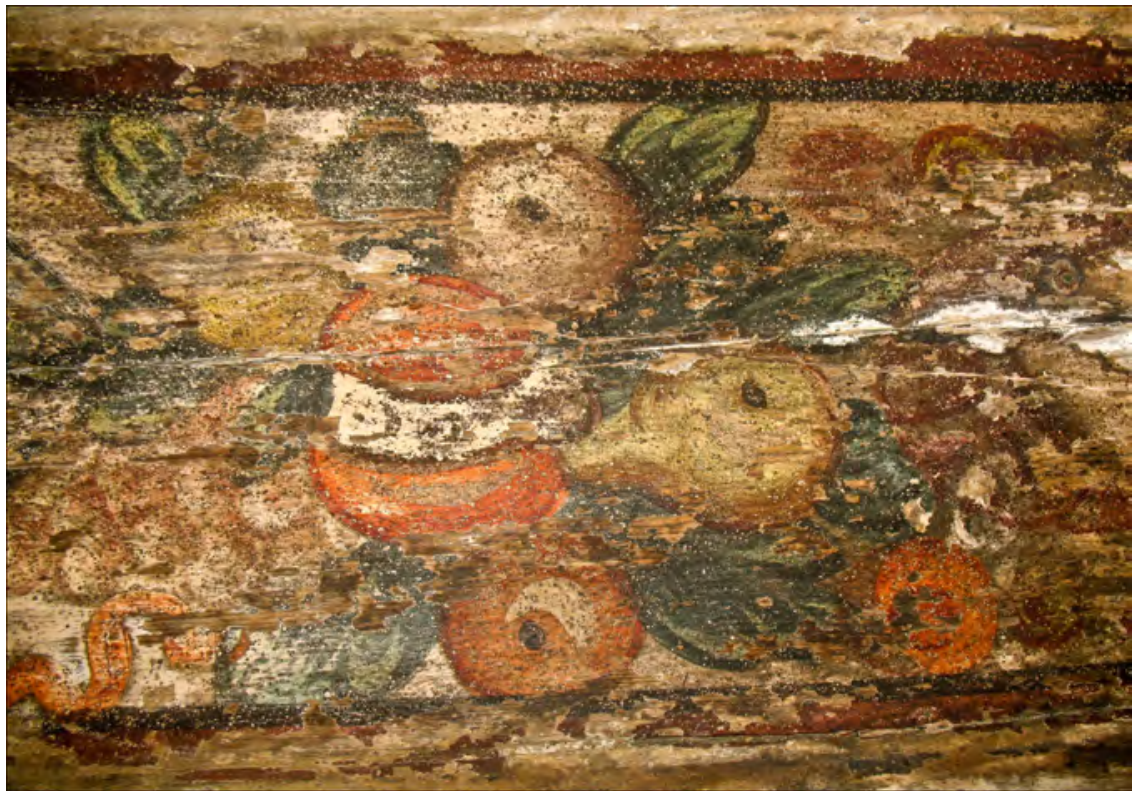

Il. 7 Pomieszczenie w trakcie tylnym parteru. XVI-wieczna polichromia w formie owocowo-kwiatowej wiązanki po oczyszczeniu przed konserwacją, fot. A. Bystroń-Kwiatkowska 


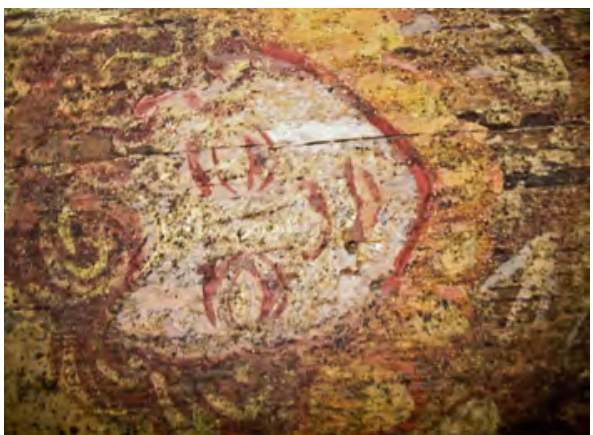

Il. 8 Pomieszczenie w trakcie tylnym parteru. XVI-wieczna polichromia w formie główki aniołka, fot. A. Bystroń-Kwiatkowska

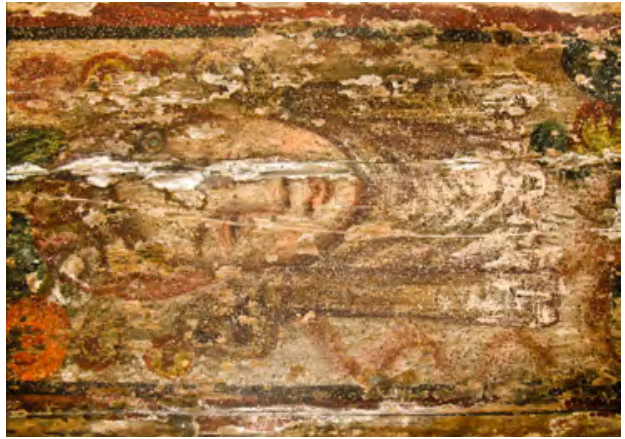

Il. 9 Pomieszczenie w trakcie tylnym parteru. XVI-wieczna polichromia w formie głowy kobiecej, fot. A. Bystroń-Kwiatkowska

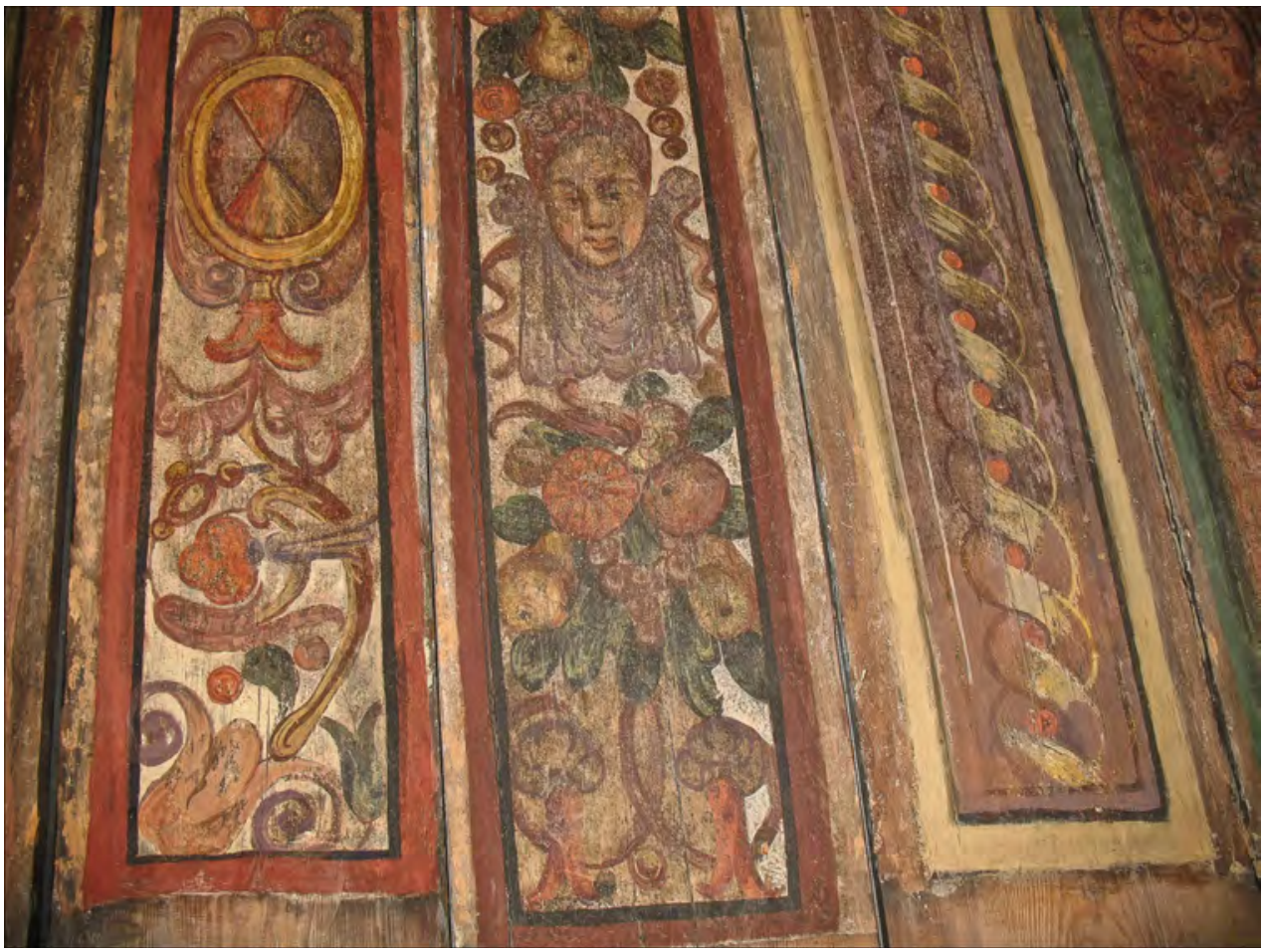

Il. 10 Pomieszczenie w trakcie tylnym parteru. Polichromowane dyle po konserwacji, fot. A. Bystroń-Kwiatkowska 


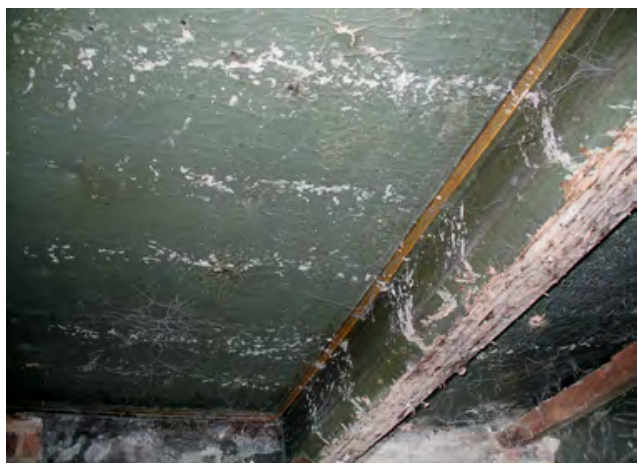

Il. 11 Pomieszczenie w trakcie tylnym parteru. Odsłonięta spod oszalowania polichromowana tkanina i obciosane belki stropu, fot. L. Czyżniewska

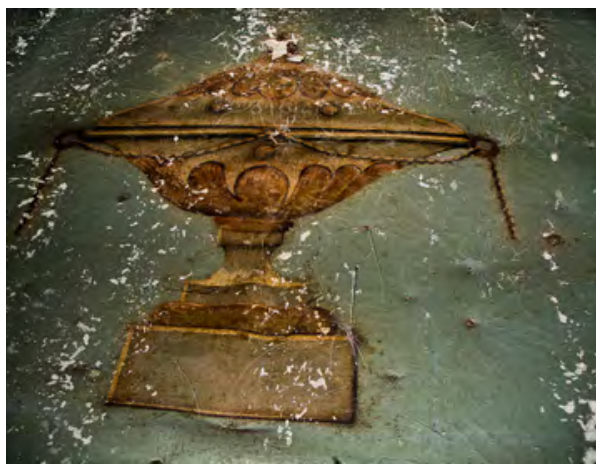

Il. 12 Pomieszczenie w trakcie tylnym parteru. XIX-wieczna waza malowana na pasmach płótna rozpostartych między belkami stropu, fot. S. Socha-Bystroń

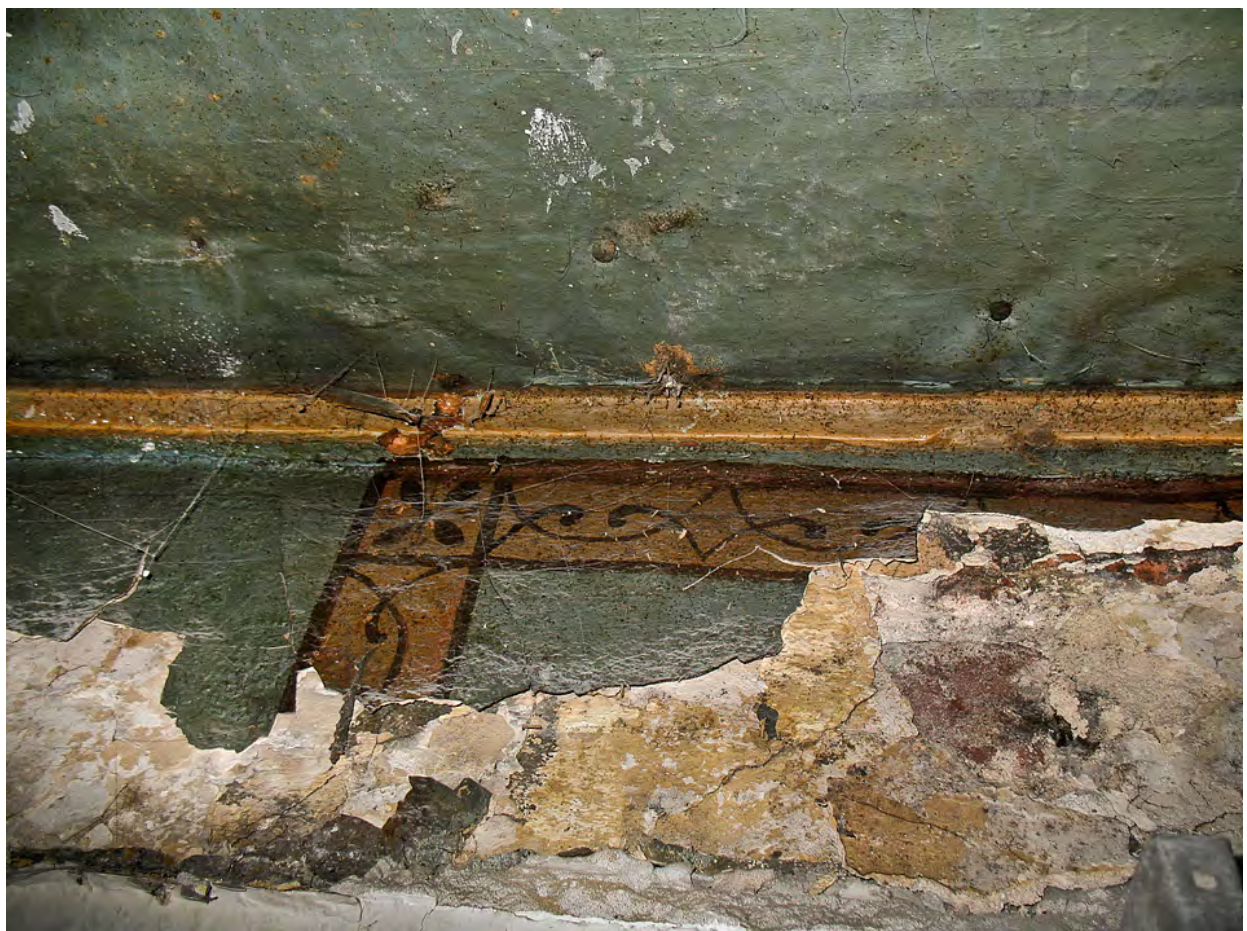

Il. 13 Pomieszczenie w trakcie tylnym parteru. Polichromia ścian - bordiura będąca kontynuacją malowideł plafonowych, fot. A. Bystroń-Kwiatkowska 


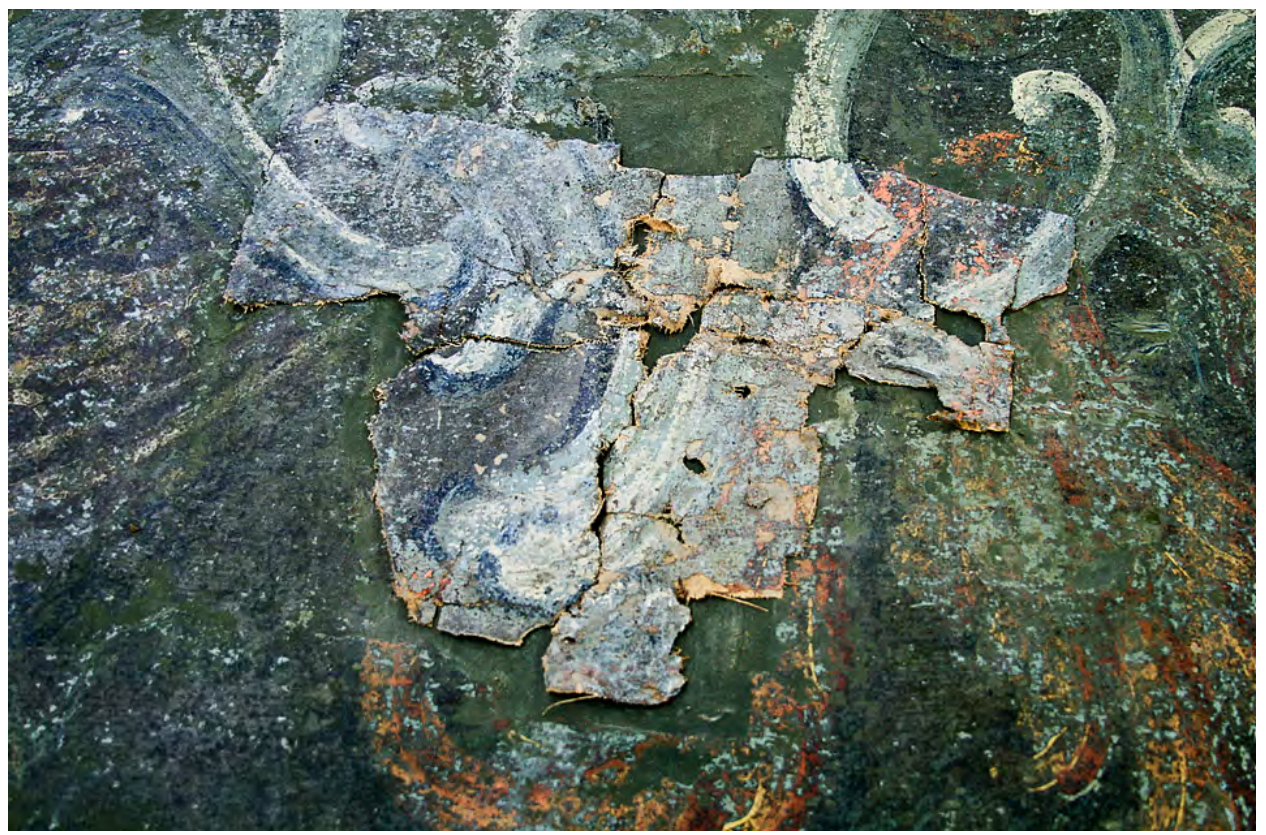

Il. 14 Pomieszczenie w trakcie tylnym parteru. Próby reperacji ubytków płótna plafonowego, ułożenie znalezionych fragmentów, fot. S. Socha-Bystroń

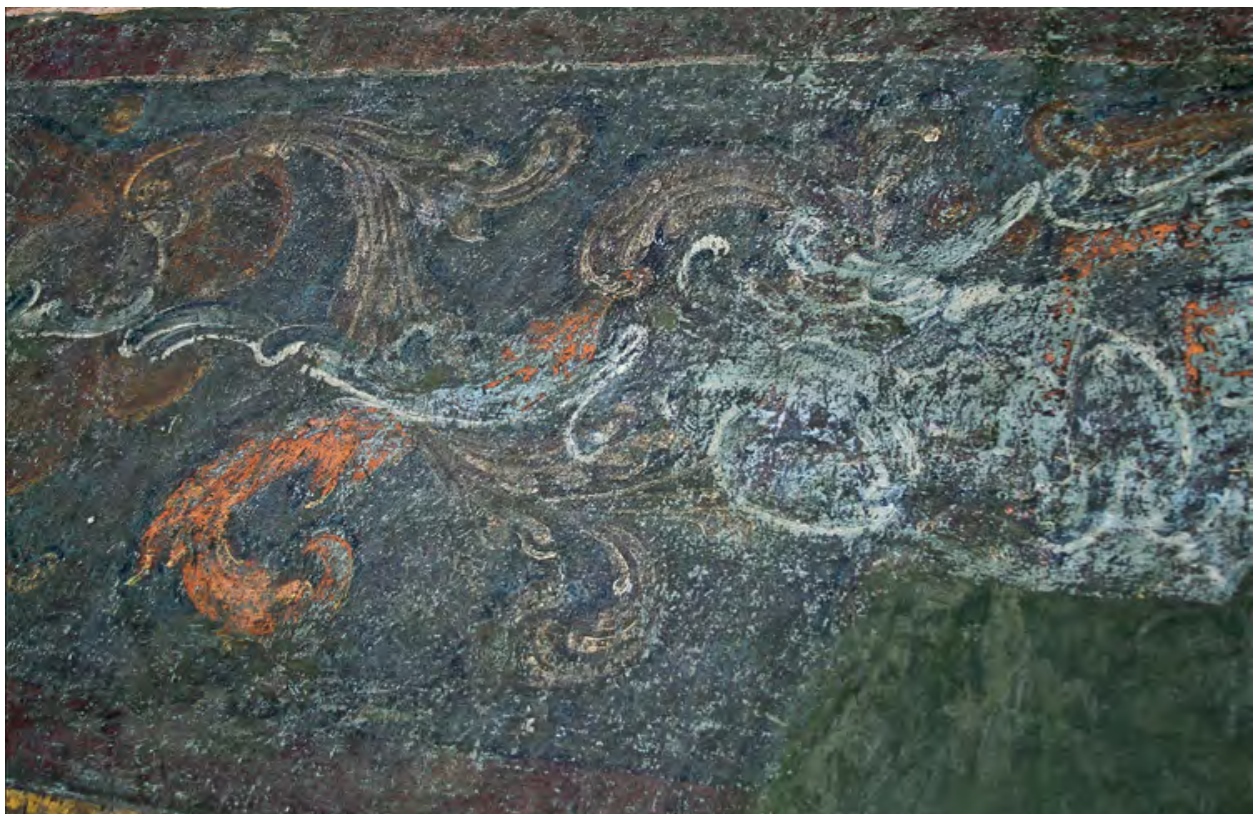

Il. 15 Pomieszczenie w trakcie tylnym parteru. Odsłonięty spod XIX-wiecznych przemalowań ornament rocaillowy plafonu i leżący pod nim ornament okuciowo-pasowy, fot. S. Socha-Bystroń 


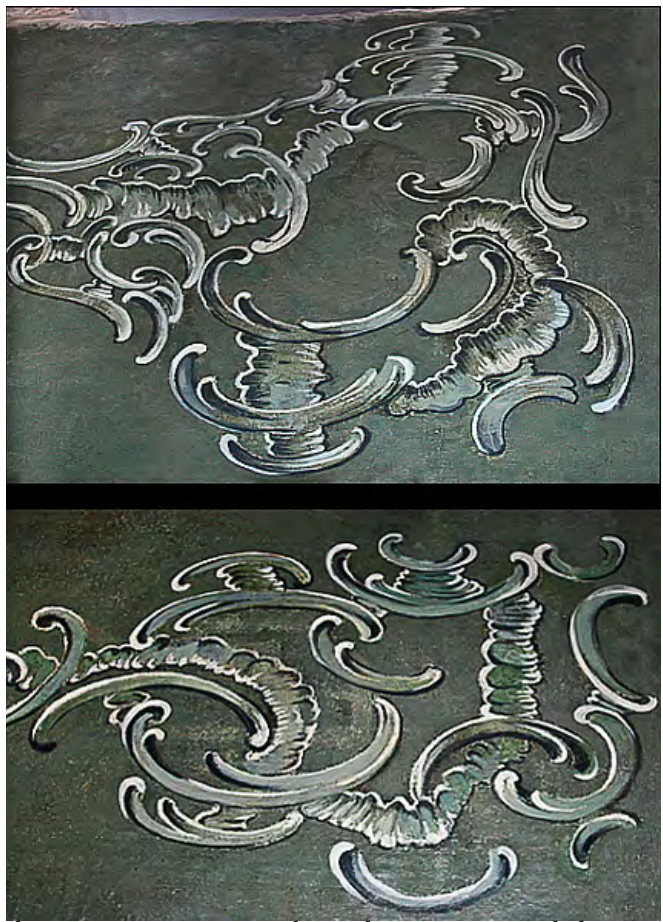

Il. 16 Pomieszczenie w trakcie tylnym parteru. Polichromowana tkanina po konserwacji, fot. S. Socha-Bystroń

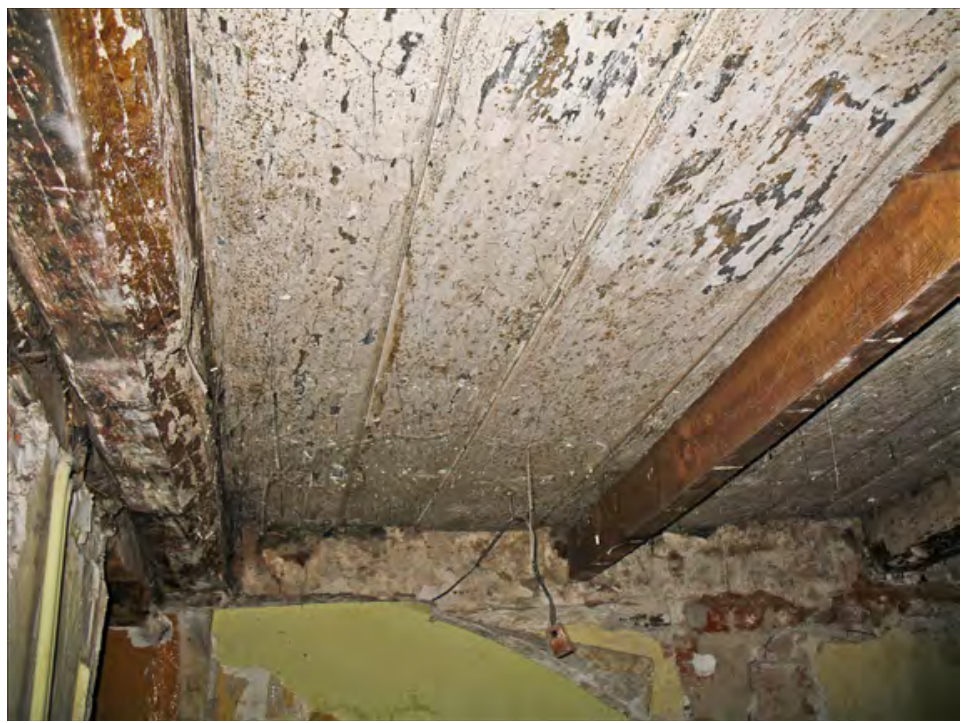

Il. 17 Pomieszczenie I piętra w tylnym trakcie. Widok stropu po odsłonięciu spod oszalowania, fot. A. Bystroń-Kwiatkowska 


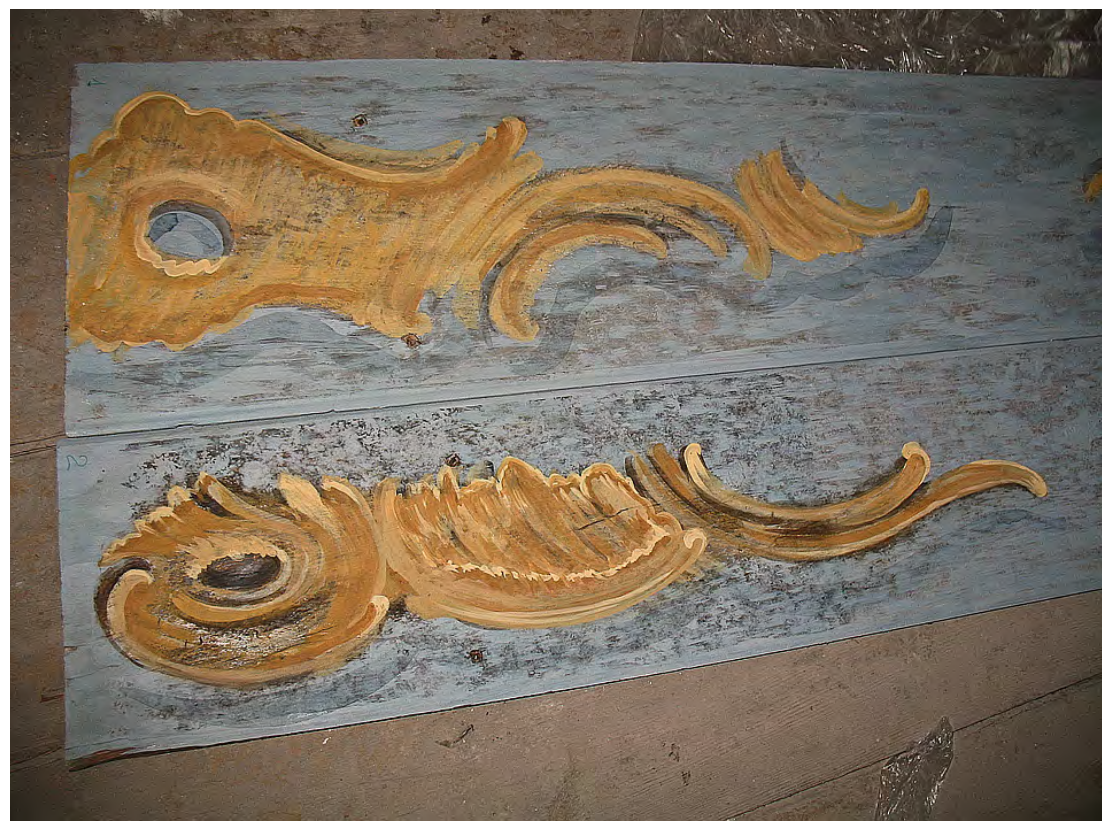

Il. 18 Belki stropu z XVIII-wieczną polichromią. Nad belkami widoczne dyle z XIII w. pokryte warstwami malarskimi, fot. A. Bystroń-Kwiatkowska

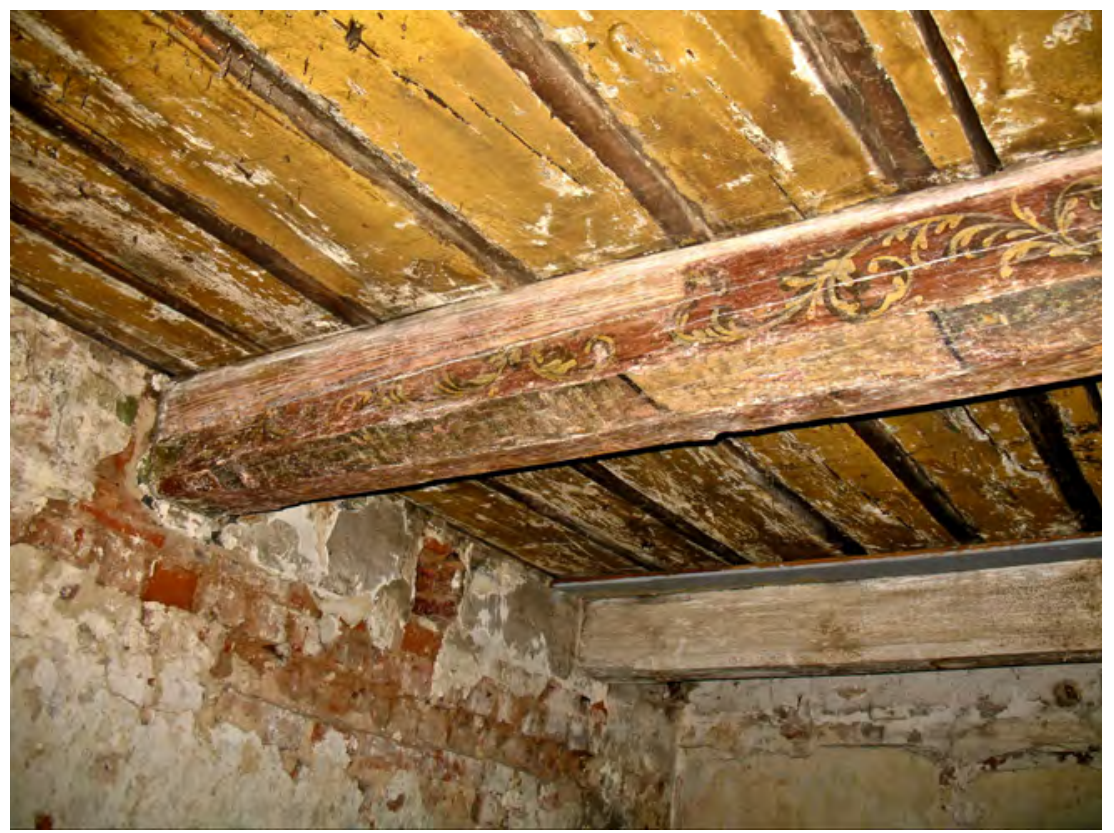

Il. 19 Pomieszczenie I piętra w tylnym trakcie. Pomieszczenie I piętra w tylnym trakcie. Rocaillowa dekoracja stropu w trakcie prac konserwatorskich, fot. A. Bystroń-Kwiatkowska 